\title{
The impact of the COVID-19 pandemic on urban farming household income in Yogyakarta City
}

\author{
Sotya Tresna Anggita ${ }^{*}$, Irham ${ }^{2}$, and Lestari Rahayu Waluyati ${ }^{2}$ \\ ${ }^{1}$ Master Students of Agribusiness Management, Department of Agricultural Socio-economics, \\ Faculty of Agriculture, Universitas Gadjah Mada, Indonesia \\ ${ }^{2}$ Department of Agricultural Socio-economics, Faculty of Agriculture, Universitas Gadjah Mada, \\ Indonesia
}

\begin{abstract}
The people of Yogyakarta City have been carrying out urban farming activities for the last decades to take advantage of their home garden. Because of the COVID-19 pandemic, their level of livelihood has been declining due to a decrease in their income level. The income decrease of the urban people who carry out urban farming can be caused by vulnerability and demographic factors. The research was conducted in Kraton and Wirobrajan Sub-districts from June to July 2020 through questionnaires filled by 65 respondents. This study aims to: estimate the current household income of urban people who carryout urban farming; determine the effect of the COVID-19 pandemic on the household income of urban people who carry out urban farming; analyze the effect of vulnerability and demographic factors on the householdincome decrease of urban peoplecarrying out urban farmingduring the COVID-19 pandemic. Wilcoxon test and multiple linear regression method are used in this study. The results indicate that the COVID-19 pandemic has significantly caused a decrease in household income for urban people carrying out urban farming. Women's main income earner and the exposure index individually have positive effects on the household income decreaseof these urban people.
\end{abstract}

\section{Introduction}

Indonesia is one of the countries affected by the COVID-19 pandemic. According [1] to the Presidential Decree of Republic Indonesia Number 12 of 2020, non-natural disaster of the Corona Virus Disease 2019 (COVID-19) has been declared as national disaster. The COVID-19 pandemic not only has an impact on public health but will also have an impact on people's incomes and livelihoods. The impact is also felt by the people in the Yogyakarta City.

The COVID-19 pandemic has had an impact on various sectors including urban people householdswho carry out urban farmingin Yogyakarta City the majority work in the fields of trade, tourism, transportation, and so on. The COVID-19 pandemic has also caused many companies to reduce production and increase the rate of layoff. Research from [2]

*Corresponding author: sotya.tresna.a@mail.ugm.ac.id 
shows the respondent who were surveyed online from 17 countries inLatin America and the Caribbean describe the COVID-19 pandemic impact on the economy that destroys many households.

Some of the urban people in Yogyakarta City include urban farming household, work in the tourism support sectors such as businesses producing food and souvenirs. They will also be affected and experienced a decrease in income due to declining demand.According to research conducted by [3], in Indonesia, there have been losses in the tourism sector due to the COVID-19 pandemic. The income decrease that occurs causes vulnerability on urban people households who carry out urban farming.In the research of [4], income is an important factor in determining the adaptive capacity of households; households having high income will also have the high adaptive capacity and have lower vulnerability. From [5] shows that financial vulnerability has a negative impact on income inequality. Therefore, the income decreaseof urban people carrying out urban farming may be caused by vulnerability and demographic factors.

According to [6], vulnerability is divided into major components into factors (indexes) that contribute to vulnerability according to the IPCC(Intergovernmental Panel on Climate Change) (Table 1). This research is unique because it discusses the factors that influence the decrease in the household income of urban people carrying out urban farming in Yogyakarta City, which has not been discussed previously.

Table 1. Factors contributing to vulnerability according to the IPCC

Source: [6]

\begin{tabular}{|l|l|}
\hline Contributing factors (indexes) & \multicolumn{1}{c|}{ Major components } \\
\hline Exposure & Natural disasters and climate variability \\
\hline Adaptive capacity & $\begin{array}{l}\text { Socio-demographic profile } \\
\text { Livelihood strategies } \\
\text { Social networks }\end{array}$ \\
\hline Sensitivity & $\begin{array}{l}\text { Health } \\
\text { Food } \\
\text { Water }\end{array}$ \\
\hline
\end{tabular}

Therefore, the aims of this study are: 1) estimate the current household income of urban people who carry out urban farming; 2) determine the effect of the COVID-19 pandemic on the household income of urban people who carry out urban farming; 3) analyze the effect of vulnerability and demographic factors on the household income decrease of urban people carrying out urban farming during the COVID-19 pandemic.

\section{Material and methods}

\subsection{Location and data collection}

The respondents surveyed were all members of three farmer groups from the Kraton and Wirobrajan Sub-districts from June to July 2020. This research was quantitative research conducted by the survey. The questionnaire was directly given to the head of the farmer group and then the head of the farmer group distributed it to other members. The number of respondents surveyed in this study was 65 urban people who carry out urban farming.

\subsection{Data analysis method}

The method used in this analysis is a descriptive method from the data that has been obtained. 
The value of household income before and during the COVID-19 pandemic was compared and then analyzed using the Wilcoxon test. This method was used because the existing data has normality problems. The Wilcoxon test was used for paired sample testing. In this test, two paired samples from the same population were used [7]. This sign test analyzed by SPSS version 26 software is used to determine whether there is a difference in the income of urban people who carry out urban farming in Yogyakarta City before and during the COVID-19 pandemic.

The research hypothesis are:

$\mathrm{HO}=$ there is no difference between the household income data ofurban people who carry out urban farming in Yogyakarta City before and during the COVID-19 pandemic.

$\mathrm{Ha}=$ there is a difference between the household income data of urban people who carry out urban farming in Yogyakarta City before and during the COVID-19 pandemic.

The test criteria are as follows:

a) If Asymp. sig. (2-tailed) $<\alpha$ then $\mathrm{H} 0$ is rejected, which means that there is a difference in the householdincome of urban people who carry out urban farming in Yogyakarta Citybefore and during the COVID-19 pandemic.

b) If Asymp. sig. (2-tailed) $\geq \alpha$ then H0 fails to be rejected, which means that there is no difference in thehousehold income of urban people who carry out urban farming in Yogyakarta Citybefore and during the COVID-19 pandemic.

The analysis used in this research is multiple linear regression. In this multiple linear regression analysis, the vulnerability factor is represented by an index from the livelihood vulnerability index (LVI) which consists of an exposure index, a sensitivity index, and an index of adaptive capacity. The indexes, major components, and sub-components are arranged based on [6] were then adjusted to conditions of urban farming households during the COVID-19 pandemic (Table 2, 3, 4). The demographic factor is represented by the respondent's age, education level, number of family members, and main income earner's gender.

According to the Gauss-Markov Theorem, based on the assumptions of the classical linear regression model, the estimator of an OLS has the lowest variance among the linear estimators. The OLS estimator in this case is the best linear unbiased estimators (BLUE), so it is necessary to test the classical assumptions, namely the normality test, multicollinearity test, and heteroscedasticity test [8]. The model used in multiple linear regression in this stochastic form is (1), SPSS version 26 software is used in this analysis:

where

$$
Y=a+b_{1} X_{1}+b_{2} X_{2}+b_{3} X_{3}+b_{4} D_{4}+b_{5} X_{5}+b_{6} X_{6}+b_{7} X_{7}+e
$$

$\mathrm{Y} \quad=$ income decrease (in thousand IDR)

a $=$ intercept

$\mathrm{bj}=$ estimator parameter coefficient where $\mathrm{j}=1,2,3 \ldots .7$

$\mathrm{X} 1$ = age (years)

$\mathrm{X} 2$ = education level (years)

$\mathrm{X} 3$ number of family members (person)

D4 = dummy main income earner by gender using dummy male 0 and female 1

$\mathrm{X} 5$ = exposure index is obtained from adding up the total value per respondent or adding up the "yes" answers for each respondent in the major component COVID-19 pandemic with sub-component statements as shown in Table 2.

X6 = sensitivity index (adding up the total value per respondent or adding "yes" answers to each respondent for each major component consisting of food, health, water, and psychological state) the sub-components used in Table 3.

$\mathrm{X} 7$ = adaptive capacity index (adding up the total value per respondent or adding "yes" answers to each respondent for each major component consisting of livelihood 
strategies, socio-demographic profile, unity participation and social network, and education) the sub-components used in Table 4.

$\mathrm{e} \quad=$ residual

Table 2. Main components and sub-components of the exposure index

\begin{tabular}{|c|c|l|}
\hline Index & Major Component & \multicolumn{1}{c|}{ Sub-Components } \\
\hline Exposure & The COVID-19 pandemic & $\begin{array}{l}\text { Family members have COVID-19 } \\
\text { Family members were sick during the pandemic } \\
\end{array}$ \\
& & $\begin{array}{l}\text { Family members lost their jobs } \\
\text { Family members having decreased income }\end{array}$ \\
\hline
\end{tabular}

Table 3. Main components and sub components of the sensitivity index

\begin{tabular}{|c|c|c|}
\hline Indexes & $\begin{array}{c}\text { Major } \\
\text { Components }\end{array}$ & Sub-Components \\
\hline \multirow[t]{4}{*}{ Sensitivity } & Food & $\begin{array}{l}\text { Have one source of income } \\
\text { Activities that are outside the home } \\
\text { Not have vegetables in the yard } \\
\text { Not have fruit-producing trees } \\
\text { Not have livestock that can be used as a food source } \\
\text { Not have fish that can be used as a food source } \\
\text { Buying sources of food were consumed }\end{array}$ \\
\hline & Health & $\begin{array}{l}\text { Far to health facilities } \\
\text { Family members who are sick } \\
\text { Elderly family members } \\
\text { Family members who are still toddlers } \\
\text { Family members have an infectious disease } \\
\text { Family members smoke }\end{array}$ \\
\hline & Water & $\begin{array}{l}\text { Difficulty getting water to water plants } \\
\text { Difficulty in obtaining water sources }\end{array}$ \\
\hline & $\begin{array}{l}\text { Psychological } \\
\text { state }\end{array}$ & $\begin{array}{l}\text { Food availability concerns are disrupted during the pandemic } \\
\text { Household worries the economic get worse and stress of job } \\
\text { loss } \\
\text { The pandemic situation disrupts the household economy }\end{array}$ \\
\hline
\end{tabular}


Table 4. Main components and sub-components of the adaptive capacity index

\begin{tabular}{|c|c|c|}
\hline Indexes & $\begin{array}{c}\text { Major } \\
\text { Components }\end{array}$ & Sub-Components \\
\hline \multirow[t]{4}{*}{$\begin{array}{l}\text { Adaptive } \\
\text { capacity }\end{array}$} & $\begin{array}{l}\text { Livelihood } \\
\text { strategies }\end{array}$ & $\begin{array}{l}\text { There is no additional outpouring of time for gardening } \\
\text { Not increase the number of potted plants } \\
\text { Not increase the type of plant } \\
\text { Not increase the number of livestock } \\
\text { Not increase the number of fishery } \\
\text { Not increase the consumption of own harvest } \\
\text { Not reduce the amount of food purchased } \\
\text { Not save the crop for some time } \\
\text { Not save seeds for replanting }\end{array}$ \\
\hline & $\begin{array}{l}\text { Socio- } \\
\text { demographic } \\
\text { profile }\end{array}$ & $\begin{array}{l}\text { The family does not support urban farming } \\
\text { Urban farming is not to reduce the food purchased and } \\
\text { being more frugal }\end{array}$ \\
\hline & $\begin{array}{l}\text { Unity } \\
\text { participation } \\
\text { and Social } \\
\text { network }\end{array}$ & $\begin{array}{l}\text { Not joining the urban farming association } \\
\text { Not attending group meetings } \\
\text { Not attend meetings at the neighborhood association } \\
\text { level } \\
\text { Not complying with neighbors' invitations by } \\
\text { implementing health protocols } \\
\text { Together with neighbors, they do not exchange crops } \\
\text { Not share information with neighbors about urban } \\
\text { farming } \\
\text { Inactive in Whatsapp group application }\end{array}$ \\
\hline & Education & $\begin{array}{l}\text { Not finding out more urban farming techniques } \\
\text { Not looking for more about production materials that are } \\
\text { suitable for urban farming } \\
\text { Not finding out more about suitable irrigation systems } \\
\text { Not have television/radio/internet to access urban } \\
\text { farming information } \\
\text { Not attend training related to urban farming } \\
\text { Not try out urban farming techniques self }\end{array}$ \\
\hline
\end{tabular}

The OLS test needs to pay attention to the $\mathrm{F}$ test, $\mathrm{t}$-test, and adjusted $\mathrm{R}^{2}$ value, so after the multiple linear regression test is carried out, a discussion of the t-test is conducted to test the partial significance of the effect between each independent variable on the dependent variable, the $\mathrm{F}$ test to know the significance of independent variables together on the dependent variable [9] and adjusted $\mathrm{R}^{2}$ to determine the proportion of the total variation of the dependent variable that can be explained by the independent variables [8].

\section{Results and discussions}

\subsection{Current household income of urban people who carry out urban farming during the COVID-19 pandemic}

In terms of income during the COVID-19 pandemic period, which was around May 2020, it was seen that most respondents (52.31\%) were less than equal to IDR 1,000,000 (Table 5). On the other hand, respondents with a higher wage than the 2020 Yogyakarta City minimum wage which is at IDR 2,004,000 based on [10] are less $(24.61 \%)$. This can occur because most of the respondents work as entrepreneurs and private employees. The type of work as entrepreneurs and private employees will be affected during the COVID-19 
pandemic due to decreased purchasing power. It is supported by research conducted by [11]impact of the COVID-19 pandemic on the Indonesian economy occurred in the transportation, tourism, trade, health, and other sectors, with the household sector being the most affected.

Table 5. Monthly household income of urban people who carry out urban farming in Yogyakarta City during the COVID-19 pandemic

\begin{tabular}{|l|c|c|}
\hline Household Monthly Income (IDR) & Number of Households & Percentage (\%) \\
\hline$\leq 1,000,000$ & 34 & 52.31 \\
\hline $1,001,000-2,000,000$ & 15 & 23.08 \\
\hline $2,001,000-3,000,000$ & 11 & 16.92 \\
\hline $3,001,000-4,000,000$ & 2 & 3.08 \\
\hline$\geq 4,001,000$ & 3 & 4.61 \\
\hline Total & 65 & 100.00 \\
\hline
\end{tabular}

Source: Primary data (2020), processed

\subsection{Effect of the COVID-19 pandemic on the household income of urban people who carry out urban farming}

From Table 6, it can be seen that the average household income of urban people who carry out urban farming during the COVID-19 pandemic around May 2020 experienced a fairly high decrease, which was more than one million rupiahs $(47.70 \%)$. The results of the Wilcoxon test analysis show that Asymp. sig. (2-tailed) of 0.000 which is smaller than alpha $1 \%, 5 \%$, and $10 \%$, so $\mathrm{H} 0$ is rejected. These results indicate that there is a significant difference between the income data of urban people who carry out urban farming in Yogyakarta City before and during the COVID-19 pandemic, where the household income of urban people who carry out urban farming decreased during the COVID-19 pandemic.

The decrease in income that occurs in respondents can be caused by several reasons such as most respondents work as entrepreneurs, especially those working in the trade, transportation, and tourism sectors. In addition, the level of consumption of public goods and services has decreased. As in research by [12], COVID-19 pandemic is causing considerable long-term and short-term impacts on informal employment and the informal economy, there is a need for greater job security to help organizations stay competitive.

Table 6. Monthly household income of urban people who carry out urban farming in Yogyakarta City

\begin{tabular}{|l|c|c|c|c|}
\hline \multicolumn{1}{|c|}{ Income } & $\begin{array}{c}\text { Before COVID-19 } \\
\text { (Rp) }\end{array}$ & $\begin{array}{c}\text { During COVID-19 } \\
\text { (Rp) }\end{array}$ & $\begin{array}{c}\text { Income } \\
\text { Change (Rp) }\end{array}$ & $\begin{array}{c}\text { Income } \\
\text { Decrease(\%) }\end{array}$ \\
\hline Main Income & $2,216,154$ & $1,214,615$ & $-1,001,539$ & 45.19 \\
\hline $\begin{array}{l}\text { Family Side } \\
\text { Income }\end{array}$ & 481,154 & 196,123 & $-285,031$ & 59.24 \\
\hline $\begin{array}{l}\text { Household } \\
\text { Income }\end{array}$ & $2,697,308$ & $1,410,738$ & $-1,286,570$ & 47.70 \\
\hline
\end{tabular}

Source: Primary data (2020), processed

The decline in population income occurred in various places such as in Salumpaga Village, North TolitoliSub-district, after the implementation of prevention of transmission of COVID-19 pandemic there has been a decrease in income for both traders, fishermen, and farmers, followed by the number of economic facilities that have been closed and followed by increased basic needs of the community [13].Declining income must be followed by new habits that can save expenses and keep trying to earn income too. Urban farming is one of the things that the community can do, especially in urban areas such as the Yogyakarta City during the COVID-19 pandemic. Urban farming is very suitable to be 
carried out in urban areas as long as people carry out physical distancing which requires people to spend a lot of time at home. Besides being able to help fulfill family food needs, this agricultural activity can also be used to spend spare time so as not to stress.

Socialization about urban farming during the COVID-19 pandemic has been carried out. From [14] socialization about urban farming and the provision of vegetable seeds was carried out in the Tafure Village of Ternate. The introduction of urban farming was also carried out in the research of [15], introduction activities were carried out for students, especially in order to fulfill food security during the COVID-19 pandemic and also to add economic value.

\subsection{Effect of vulnerability and demographic factors on the household income decrease of urban people carrying out urban farming during the COVID-19 pandemic}

\subsubsection{Classical assumptions test}

This classical assumption test is used to test whether there are problems of normality, multicollinearity between variables, and heteroscedasticity. According to the Shapiro-Wilk test the residuals are normally distributed because the p-value obtained is 0.081 greater than the $5 \%$ error rate so it is not significant, the residuals are normally distributed. The multicollinearity test according to the VIF value shows that the independent variables all have a value of less than 10 , so there is no multicollinearity problem. The next classic assumption test is heteroscedasticity, from the Breusch-Pagan test it shows that there is no heteroscedasticity problem. This is because the p-value of the F test on the Breusch-Pagan test is 0.114 this p-value is greater than the $10 \%$ error rate, so the heteroscedasticity test value is not significant.

\subsubsection{Vulnerability and demographic factors affecting income decrease}

\section{Goodness of Fit Test}

Table 7 shows that the adjusted $\mathrm{R}^{2}$ value is 0.316 or $31.6 \%$. This value indicates that the independent variables in the form of respondent's age, education level, number of family members, dummy main income earner by gender, exposure index, sensitivity index, and adaptive capacity index of urban people who carry out urban farming in Yogyakarta City can explain $31.6 \%$ of the variation of the dependent, namely income decrease. Then $68.4 \%$ of the variation in the dependent variable is explained by other variables not included in the model.

F-test

From Table 7 it is known that the sig-F value of 0.000 is smaller than $\alpha(1 \%, 5 \%$, and $10 \%)$ so that $\mathrm{H} 0$ is rejected, meaning that the independent variables in the form of respondent's age, educationlevel, number of family members, dummy main income earner by gender, the exposure index, sensitivity index, and adaptative capacity index together have a significant effect on the dependent variable, namely income decrease. 
Table 7. Results of multiple linear regression analysis of factors affecting the householdincome decrease (000) of urban people who carry out urban farming due to the COVID-19 pandemic

\begin{tabular}{|l|c|c|c|c|}
\hline \multicolumn{1}{|c|}{ Variables } & $\begin{array}{c}\text { Regression } \\
\text { Coefficient }\end{array}$ & Std. Error & t & sig-t \\
\hline C & $-1,186.059$ & $1,269.722$ & -0.934 & 0.354 \\
\hline Age & -8.448 & 11.234 & -0.752 & 0.455 \\
\hline Education level & 82.363 & 49.484 & 1.664 & 0.102 \\
\hline $\begin{array}{l}\text { Number of family } \\
\text { members }\end{array}$ & 144.762 & 91.077 & 1.589 & 0.117 \\
\hline $\begin{array}{l}\text { Dummy main income } \\
\text { earner by gender }\end{array}$ & $614.176^{* *}$ & 284.420 & 2.159 & 0.035 \\
\hline Exposure Index & $707.485^{* * *}$ & 161.393 & 4.384 & 0.000 \\
\hline Sensitivity Index & 34.542 & 77.124 & 0.448 & 0.656 \\
\hline $\begin{array}{l}\text { Adaptive capacity } \\
\text { Index }\end{array}$ & -45.959 & 29.220 & -1.573 & 0.121 \\
\hline Adjusted R-squared & & & & 0.316 \\
\hline F & & & & $5.227 * * *$ \\
\hline Sig-F & & & & 0.000 \\
\hline
\end{tabular}

Notes: $(* *$ and $* * *)$ are significant at the $95 \%$ and $99 \%$ levels

Source: Primary data (2020), processed

\section{t-test}

One of the impacts of the COVID-19 pandemic is causing urban people who carry out urban farming to experience a decrease in income. From the results of multiple linear regression analysis (Table 7) using independent variables in the form of respondents' age, education level, number of family members, dummy sources of main income earner by gender, exposure index, sensitivity index, and adaptive capacity index, the results showed that the dummy of main income earner by gender and exposure index have a significant effect on the income decrease of urban people household who carry out urban farming in Yogyakarta City.

\section{Main income earner by gender}

The regression coefficient for main income earner by gender is positive (Table 7), meaning that if the source of income comes from someone who is women, it will cause a greater decrease in income compared to someone who is men. The decrease in income for gender as the main source of men income is lower because in a company it is possible to retain men employees. In addition, people who are men are usually the head of the household. It is supported by research [16] the obligations between men and women are different which causes different productivity, so the income earned can also be different in Indonesia.

\section{Exposure index}

The LVI according to the IPCC consists of an exposure index, a sensitivity index, and an adaptive capacity index [6]. Of these three indices that have a significant effect is the exposure index. The sensitivity index consists of one of which is food. Food derived from urban farming activities can help fulfill the family's food needs. The adaptive capacity index can be one of the things that show how the level of adaptation of urban people household who carry out urban farming in Yogyakarta City. Good adaptation of urban people who carry out urban farming like implementing urban farming optimally will be able to reduce the vulnerability of households.

The regression coefficient of theexposure index generated is 707.485 in (000) meaning that if the exposure index of the respondent increases by 1 unit, it will increase the income declineby IDR 707,485. Otherwise, if the respondent's exposure index decreases by 1 unit, 
it will cause a decrease in the income declineby IDR 707,485 assuming other factors are constant.

The exposure index due to the non-natural disaster COVID-19 is an impact felt by respondents. A higher exposure index value means that people are increasingly feeling the impact of the COVID-19 pandemic, resulting in a higher decrease in income. Urban people who carry out urban farming who are exposed to the COVID-19 pandemic can experience family members getting sick, decreased income, and losing their jobs. Urban farming activities can be used to reduce food expenditure, so as to reduce the exposure of urban people who carry out urban farming due to the COVID-19 pandemic. The research of [17], obtained results that the COVID-19 pandemic affected a decrease in the income of MSMEs in Bantar Jaya Bogor Village during the COVID-19 pandemic.

\section{Conclusions}

During the COVID-19 pandemic, the household income of urban people who carry out urban farming was dominated less than equal to IDR $1,000,000$. The impact of the COVID19 pandemic has caused a decrease in the household income of urban people who carry out urban farming in Yogyakarta City. Women's main income earner and exposure index individually have a positive effect on the decrease in household income. Urban people who carry out urban farming affected by the COVID-19 pandemic must be able to adapt, one of which is by using their agricultural products to reduce food expenditure.

\section{References}

1. JDIH BPK RI, Penetapan bencana non alam penyebaran Corona Virus Disease 2019 (COVID-19) sebagai bencana nasional URL: https://peraturan.bpk.go.id/Home/Details/135718/keppres-no-12-tahun-2020 (2020)

2. N. Bottan, B. Hoffmann, D. Vera-Cossio, PLoS ONE, 15,1-10,(2020).

3. J. H. V. Purba, R. Fathiah, Steven. Jurnal Aplikasi Ekonomi, Akuntansi dan Bisnis. 3, 389-401 (2021).

4. A. M. Ado, J. Leshan, P. Savadogo, S. K. Koivogui, J. C. Pesha, J. Environ. Earth Sci. 8, 3, (2018).

5. N. Apergis, Bulletin of Monetary Economics and Banking. 21, 395-408, (2019).

6. M. B. Hahn, A. M. Riederer, S. O. Foster. Glob. Environ. Change. 19, 74-88, (2009).

7. S. Santoso, Statistik Nonparametrik : Konsep dan Aplikasi dengan SPSS (PT Elex Media Komputindo, Jakarta, 2010).

8. D. N. Gujarati, Dasar-Dasar Ekonometrika Jilid I (Penerbit Erlangga, Jakarta, 2007).

9. S. Riyanto, A. A. Hatmawan. Metode Riset Penelitian Kuantitatif Penelitian di Bidang Manajemen, Teknik, Pendidikan dan Eksperimen (Deepublish, Sleman, 2020).

10. Pemda Daerah Istimewa Yogyakarta, UMK Kabupaten/Kota Tahun 2021. Telah Ditetapkan URL: https://www.jogjaprov.go.id/berita/detail/8996-gubernur-diy-telahtetapkan-umk-kabupaten-kota (2020).

11. Susilawati, R. Falefi, A. Purwoko, BIRCI-Journal 3. 1147-1156 (2020).

12. A. Webb, R. McQuaid, S. Rand,Int. J. Sociol. Soc. Policy. 40, 1005-1019 (2020).

13. Ferdi,Geography Science Education Journal (GEOSEE). 1, 2, (2020).

14. R. Melati, S. Sudjud,Sarni, Jurnal Pengamas. 3, 2, (2020).

15. D. N. Ahmad, L.Setyowati,J. Pengabdi. Magister Pendidik. IPA. 4, 208-212, (2021).

16. M. Akbariandhini, A. F. Prakoso. Jurnal Pendidikan Ekonomi, Manajemen dan Keuangan. 4, 13-22, (2020).

17. G. N. Khaeruddin, K. Nawawi, A. Devi, Jurnal Akrab Juara. 5, 86-101, (2020). 